\title{
The Correlation Between Students' Motivation and Their Speaking Ability
}

\author{
Aning Widayanti \\ Faculty of Education and Teachers Training \\ UIN Sunan Ampel \\ Surabaya, Indonesia \\ Dwi Amanatun Nafisah \\ Facu;ty of Education and Teachers Training \\ UIN Sunan Ampel \\ Surabaya, Indonesia
}

\author{
Ahsanatul Munawwaroh \\ Facu;ty of Education and Teachers Training \\ UIN Sunan Ampel \\ Surabaya, Indonesia \\ Nur Fadilah \\ Facu;ty of Education and Teachers Training \\ UIN Sunan Ampel \\ Surabaya, Indonesia
}

\author{
Milatul Islamiyah \\ Facu;ty of Education and Teachers Training \\ UIN Sunan Ampel \\ Surabaya, Indonesia
}

\begin{abstract}
Speaking is one of important skill for all students that every student should master it. In the modern era, some students may be not all of them have a good speaking in English. To help their ability to speak, the students should have a high motivation, fine extrinsic or intrinsic motivation. Motivation is an internal condition that exists in humans which can encourage someone to act ina certain direction and engage in certain activities. The purpose of this research is to find out the relationship between students' motivation in learning speaking and speaking ability at State Islamic University of Sunan Ampel Surabaya. To collect the data, the researchers distributed the questionnaire to 30 students of English Teacher Education Department in the third semester who have taken spoken English Class in 2018 to know the students' motivation and their speaking ability. It was discoverd that the students of English Teacher Education Department have not high motivation. Next, from the Spoken English final score, it was found that the students have a high score in speaking ability. It can conclude that there is no positive correlation between students' motivation in learning speaking and their speaking ability. In other words, there is no significant correlation between English Teacher Education Department students in State Islamic University of Sunan Ampel Surabaya with their speaking ability.
\end{abstract} ability

Keywords: motivation, students' motivation, speaking

\section{INTRODUCTION}

Speaking is one of the English skills that is difficult for some students to master in the world.This is a complex skill among three other skills in English. Many Indonesian students have difficulty learning to speak let alone practicing it. Nerfi (2013) states that learning speaking skills not only learns about language itself but also learn show to speak in real communication. Many Indonesian students do not speak English either in class or in real communcation this could be because English is not the imative language so English is rarely used in daily life when they interact with each other.

To be success in speaking English can be achieved if students are in situation where they must speak English. Besides, students must have aa inner desire to talk. From this, it can be seen if in learning to speak, students are influenced by several things, one of which is motivation. Motivation has an important role to develop students' speaking skills. Harmer (1991) stated that motivation is an energy that can encourage students to do something both coming from inside or from outside. In terms of speaking, motivation will provide strength for students to learn speaking. As for motivate students, they will do anything to support their performance. They will do their best to achieve the best results.

Motivation has a crucial role in the process of learning a language. Several studies have report that motivation has an important role in encouraging someone to do something more rapidly and effectively. Nerfi (2013) studied that there is a connection between students' motivation in learning speaking and their 
A.

Behaviour

motivation in learning, they will have a good ability in speaking. Another previous study from Krashen (1981), he claims that with high motivation, self-confidence, lowself-esteem, and debilitating anxiety formed a mental block that the students had a good motivation, they had more inner state of need or desire that activate and individual to do something to satisfy them. Motivation drives an individual to take a positive effect on their life.

Based on previous research above, we conduct our research about the correlation between students' motivation and their speaking ability. In addition, we want to know about how the significant of the correlation between motivation and speaking ability on university students. The researchers mentioned earlier involved secondary school students as their subject, but no one of them focuses on college students, so that, we choose English Teacher Education Department of Islamic University of Sunan Ampel Surabaya to be our subject. We choose university students because in college, there is an English major which they are closer and more often to use English, whether in the classroom or in their daily life.

The differences in this study with the previous study are in the data collection. In this article, we distributed questionnaires to the students of English Education Department at State Islamic University of Sunan Ampel Surabaya who have taken Spoken English Course in the second in 2018. we also took the students' final score of Spoken English class to get the data. It was different with researchers before. In the previous study, the researchers test the students' speaking by a conversation in pair and distribute the questionnaire to know students' motivation. We use students' speaking final score to chheck students' ability in speaking because the final score of speaking has covered all activities in speaking class. If we take the score of speaking by students' conversation directly, the data may not be valid because the students may prepare or memorize the text before the conversation process. The problem of this research can be formulated below:

1. What is the level of students' motivation in Spoken English course at State Islamic University of Sunan Ampel Surabaya?

2. What is the average of students'speaking score in Spoken English course at State Islamic University of Sunan Ampel Surabaya?

3. How significant is the correlation between the students'motivation and theirspeaking ability at State Islamic University of Sunan Ampel Surabaya?

\section{LITERATURE REVIEW}

\section{Definition}

Motivation is one of important factors to encourage people to do something more rapidly and effectively. Elliot (2000) states that motivation as an internal state that arouses someone to act pushes someone in particular directions, and keeps engaged in certain activities. It means that motivation has a crucial role in everything we will door someone's activities. It has a powerful for us to gain the best in doing something. Santrock (2004) said that motivation is the porcess to energize, direct, and sustain behaviour. So, motivation is a porcess that encourages and shows someone to do something and continue to do activities.

In educational area, motivation is required. Motivation will make teaching and learning process be come easier and captivating. It is very good for both teacher and students to motivate each other in teaching and learning process. As Schunk (2012) opinion he states that motivation is something that can keep them from doing things based on their goals and to stay on the right path. Based on the experts' opinion above, motivation is very crucial thing in the teaching and learning process. The students who have a high motivation will be easier to get the succes and achieve their goal in learning process than those who do not have.

\section{Types of \\ Motivation}

Schunk (2012) classifies motivation into two part, they are extrinsic motivation and intrinsic motivation.

a. Extrinsic

Extrinsic motivation is a caused by the number of outside factors such as the need for passing an examination and the hope of financial reward. Marsh (2010) informed that extrinsic motivation is experienced by students is unconnected with the task earn approval for the particular behavior. An extrinsic motivation is caused by factors from outside for example, when the students avoid punishment, receive a reward, or in some other way.

Actually many other factors can influence students' extrinsic motivation in teaching and learning process as follow:

1) Teacher 
A teacher is a person who plays an essential role in teaching and learning process. The teacher is not only educationg the students and transfering the knowledge to students. A teacher should be a motivator who always motivates and supports the students in teaching and learning. Dornyei (1998) stated that the teacher's capability motivate his/her students can be identified during the teaching and learning process. Teacher has an important role in handling and organizing students in the classroom.

The teacher has an obligation to a rise motivation to the students because the teacher has the responsibility to make teaching and learning process get the success and become more interesting so they will have the desire in learning process.

\section{2) Parents}

The role of parents can affect students' extrinsic motivation in the learning process. Parents have a big influence on their children as students at school. They are also expected to motivate their children to achieve their goals in school. Harmer (1991) stated that if parents strongly oppose the culture of this language it might have a negative impact on their motivation. If they strongly support language, this might have the opposite effect. It means that parents have a crucial role in raising their children's motivation. They must support their children to create their motivation in learning, so that their children will more easily achieve good goals at school.

\section{3) Environment}

Good environment causes students' motivation. According to Tabrani (2003), the environment is everything which exists around us, which has correlation and gives influence to ourselves. So, if teaching and learning activity is done in a clean, good and healthy environment, it will provide better satisfaction for teachers and students. If the environment of the classroom is comfortable, the students will be more interesting and enjoy the class.

\section{b. Intrinsic Motivation}

Intrinsic motivation is appeared from inside of ourselves. Schunk (2012) says that "intrinsic motivation refers motivation concerned in activities for its own sake”. Intrinsic motivation is a motivation to do something from its own desire. The students who have intrinsic motivation will study hard and enjoy the teaching and learning process because they have a good desire to do everything from inside themselves. As Gardner in Senad Becirovic (2017) states that motivation is divided into three main components which are effort, desire, and favourable attitudes.
Students will do their activities because they have desires and gifts from themselves and they do not depend on external rewards. Harmer (1991) states that intrinsic motivation takes an important role in student language learning outcomes. If students have intrinsic motivation, they will be more enthusiastic in learning. Students who have intrinsic motivation will also be faster and simpler to achieve their goals because they have motivation in themselves.

\section{B. Speaking Ability}

\section{Definition}

Speaking is an interactive process of constructing meaning that involves producing, receiving, and processing information. Brown (2004) in Sidik (2013) emphasizes that speaking is a skill in producing an oral language. Another expert, Nunan (1991) in Sidik (2013) stated that mastering the art of speaking is the single most important aspect of learning the second or foreign language, and success is measured in terms of the ability to carry out the language conversation in language. So, speaking is a two-way process involving a true communication of ideas information or feelings.

Speaking is defined by Jo Mc Dough and Christopher (1993) as a desire and purpose-driven that involves expressing ideas, opinions, a wish or a desire to do something, negotiating, and solving a certain problem or maintaining social relationship and friendship. Then, Caroline (2005) states that speaking is a basic oral communication among people in society. Moreover, Kayi (2006) states that speaking is the process of building and sharing meaning through the use of verbal and non-verbali in a variety of context. It can be concluded that speaking is a language skill which has a function as communcation. Speaking is an oral activity as communication by two or more than two people in face to face.

\section{The Goal of Speaking}

Scrivener (2005) in forms that fluency and selfconfidence are important goals in the speaking class.It means that speaking trains students to have fluency and confidence in communicating with others. Fluency isused to describe the ability to communicate the intended message, and is expected to be accurate so that listeners easily get points from the message. The purpose of teaching speaking is to encourage students, to develop the ability, to communicate and interact with others, to develop fluency and be natural inexpressions and to have 
the courage to share their ideas, feelings, and opinions with others. Basically, the purpose of speaking is to communicate, as Henry (1985) says "the purpose of speech is to communicate". Speeches have three general objectives" to provide information, to entertain and persuade".

\section{The Stages of Speaking Skill}

Brown (2004) states five stages of speaking performance. They are imitative, intensive, responsive, interactive, and extensive:

a. Imitative : the ability to simply imitate a word or phrase or possibly a sentence.

b. Intensive : the production of short stretches of oral language designed to demonstrate competence in a narrow band of grammatical, phrasal, lexical or phonological relationship.

c. Responsive : this performance includes interaction and test comprehension, but at the some what limited level of a very short conversation, standard greetings, small talk, simple request and comments.

d. Interactive : in this stage, the length and complexity of the conversation is more than responsive stage, which sometimes includes multiple exchanges and/or multiple participants.

e. Extensive : extensive oral production includes speeches, oral presentations and story telling. Chelbi (2010) says that there are seven categories related to the types of oral production that the learners are supposed to accomplish in the class. They are imitative speaking, intensive speaking, responsive speaking, interactive speaking, extensive (monologue) speaking, interpersonal (dialogue), and transactional (dialogue). As we said before, the stages of speaking according to Brown (2004) is the same as Chelbi (2010). But, Chelbi (2010) adds interpersonal (dialogue), and transactional (dialogue) as the stages of speaking.

f. Interpersonal (dialogue) : it refers to maintain a social relationship than to deliver specific information to people or listener.

g. Transactional (dialogue) : a transaction is an extended for of responsive language and students are given the opportunity to negotiate what they say.

\section{Students' Motivation and Speaking Ability}

Speaking is such an important skill beside other language skills that must be learned by English students. It is a key criterion to consider whether English students competencies are good or not. Speaking skill is used by everyone to communicate in everyday life, both at school and outside of school. This can be done by two or more people to communicate, to share information and to achieve certain goals. However, based on the writer's observation in teaching speaking, many students feel ashamed to speak in class. They also fear being laughed at by their friends when speaking.

Motivation is an energy that can encourage students to do something both coming from inside or from outside. Motivation is considered as an essential part of learning speaking. It affects students' ability to speak up eagerly without feeling shy. Murcia (1991) states that the goals of speaking are to motivate the acquisition of communication skill of students and to provide real communication inside and outside of the classroom. Motivation is indispensable for teaching and learning activity. It can be the factors of success in learning a foreign language. It is in accordance with Levpuscek \& Zupancic (2008) that states that motivation is one of the internal factors that determine the rate of success in students learning.

Students' motivation becomes an important part of giving the influences on the students to push themselves to get their goals and interests in learning. The students who have higher motivation will get a better opportunity to achieve the goal in their learning activities than the lower one. According to Harmer (1991), there are some factors that influence students' motivation such as the society, the people who are close to them, the teacher and the method that the teacher used in the classroom. A teacher should encourage and support the students to speak up, and also help them to feel enjoy by making an interesting situation in the learning process. Therefore, a teacher has a vital role in teaching and learning to create motivation among students.

\section{METHOD}

\section{A. Research Setting}

The study was conducted in English Teacher Education Department, especially the third semester students of State University of Sunan Ampel Surabaya. There are around 90 students of English Education Department in the third semester in 2018.

\section{B. Participants}

Participants for the study were the third semester students of English Education Department who have taken Spoken English Course in the second semester in 2018. There are 30 students of English Education 
Department in $3^{\text {rd }}$ semester, male and female that being as the participant of this study.

\section{Materials}

This research adopted the questionnaire that was developed by R.C. Gardner, Ph. D. The questionnaire is AMTB (The Attitude Motivation Test Battery). AMTB is applied to identify the English Education Department students' motivation. The questionnaire consists of 2 indicators; intrinsic and extrinsic motivation. Intrinsic motivationis divided into three; the teacher, the parents, and the environment. Extrinsic motivation also consists of three different kinds; desire, effort, and attitude. For the speaking ability, the researcher used the students' score in Spoken English course.The reason of the researcher chose the students' score rather than other instrument was because the final score of speaking has covered all activities in the speaking class.

\section{Procedure}

The researchers distributed the questionnaire to 30 third semester students of English Teacher Education Department who have taken Spoken English Class in 2018 during their free time in the campus. The researcher asked

\begin{tabular}{|c|l|l|l|l|l|l|}
\hline & N & Min. & Max & Sum & Mean & $\begin{array}{c}\text { Std. } \\
\text { Devia } \\
\text { tion }\end{array}$ \\
\hline $\begin{array}{c}\text { All } \\
\text { item } \\
\text { of } \\
\text { extrin } \\
\text { sic } \\
\text { motiv } \\
\text { ation }\end{array}$ & $\mathbf{3 0}$ & $\mathbf{3 . 4 0}$ & $\mathbf{5 . 3 3}$ & $\mathbf{1 3 6 . 3 3}$ & $\mathbf{4 . 5 4 4 4}$ & $\mathbf{4 6 8 8 2}$ \\
\hline
\end{tabular}

the students to complete the questionnaires that consist of 30 questions. In the questionnaire, the students were asked to choose the best answer or mark the statements based on their own. Then, the researcher translated the questionnaire into the Indonesian language in order to make the students easily to read and answer the questions in the questionnaires. Next, for taking the score of speaking, the researchers also asked the students to write their own fina score of Spoken English Class in the personal information in the questionnaire.

\section{E. Data coding and analysis}

After collecting the data, the researcher analyzed the data and correlated between questionnaire results and the students' speaking score. The data from this study were analyzed using the SPSS program. With SPSS program, the researcher got the $r$ coefficient (Pearson Correlation) that can describe the correlation between $\mathrm{X}$ variable and $\mathrm{Y}$ variable, as below:

\begin{tabular}{|c|l|}
\hline Size of Correlation & \multicolumn{1}{|c|}{ Interpretation } \\
\hline $\mathbf{0 . 0 0}-\mathbf{0 . 2 0}$ & $\begin{array}{l}\text { The correlation between } \mathrm{X} \\
\text { variable and Y variable is very } \\
\text { weak or can be say there is no } \\
\text { correlation between the } \\
\text { variables. }\end{array}$ \\
\hline $\mathbf{0 . 2 0}-\mathbf{0 . 4 0}$ & $\begin{array}{l}\text { The correlation between } \mathrm{X} \\
\text { variable and Y variable is weak. }\end{array}$ \\
\hline $\mathbf{0 . 4 0}-\mathbf{0 . 7 0}$ & $\begin{array}{l}\text { The correlation between } \mathrm{X} \\
\text { variable and Y variable is enough. }\end{array}$ \\
\hline $\mathbf{0 . 7 0}-\mathbf{0 . 9 0}$ & $\begin{array}{l}\text { The correlation between } \mathrm{X} \\
\text { variable and Y variable is strong. }\end{array}$ \\
\hline $\mathbf{0 . 9 0}-\mathbf{1 . 0 0}$ & $\begin{array}{l}\text { The correlation between } \mathrm{X} \\
\text { variable and Y variable is very } \\
\text { strong. }\end{array}$ \\
\hline
\end{tabular}

\section{RESULT}

\section{A. The level of students' motivation}

Based on the table below, it can be seen that the minimum score of extrinsic motivation is 3.40 , the maximum is 5.33 , the sum is 136.33 , and the mean is 4.54 with the standard deviation 0.468 . In the other side, the minimum score of intrinsic motivation is 4.07, the maximum is 5.73 , the sum is 141.53 , and the mean is 4.46 with the standard deviation of 0.46 .

Descriptive Statics

The Table below is the descriptive statistics of all students' motivation:

\begin{tabular}{|l|l|l|l|l|l|c|}
\hline & N & Min. & Max & Sum & Mean & $\begin{array}{c}\text { Std. } \\
\text { Devia } \\
\text { tion }\end{array}$ \\
\hline $\begin{array}{l}\text { Moti } \\
\text { vatio } \\
\text { n 1 - }\end{array}$ & $\mathbf{2 9}$ & $\mathbf{4 . 1 0}$ & $\mathbf{5 . 4 3}$ & $\mathbf{1 3 6 . 5 7}$ & $\mathbf{4 . 7 0 9}$ & $\mathbf{4 1 1 1 4}$ \\
\hline
\end{tabular}




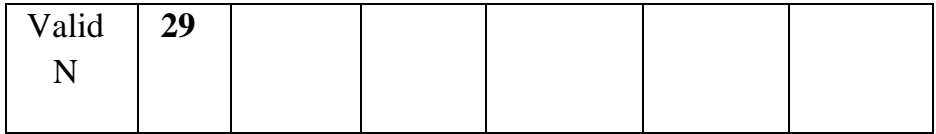

Based on the result of the statistic above, it can be seen that the total of students' motivation is 136.57 and with the minimum score is 4.10 and the maximum score is 5.43 while standard deviation is 0.41 .

\section{B. The average of students' speaking score}

In this case, the students' speaking ability is the dependent variable (Y) and the data are conducted through the questionnaire where the students are asked to fulfil their score of Spoken English course in the $2^{\text {nd }}$ semester.

\begin{tabular}{|c|c|}
\hline Students ID & $\begin{array}{c}\text { Score of Spoken } \\
\text { English course }\end{array}$ \\
\hline 1 & 35 \\
\hline 2 & 37,5 \\
\hline 3 & 37,5 \\
\hline 4 & 37,5 \\
\hline 5 & 37,5 \\
\hline 6 & 37,5 \\
\hline 7 & 40 \\
\hline 8 & 40 \\
\hline 9 & 40 \\
\hline 10 & 40 \\
\hline 11 & 37,5 \\
\hline 12 & 35 \\
\hline 13 & 37,5 \\
\hline 14 & 27,5 \\
\hline 15 & 37,5 \\
\hline 16 & 32,5 \\
\hline 17 & 35 \\
\hline 18 & 37,5 \\
\hline 19 & 40 \\
\hline
\end{tabular}

\begin{tabular}{|c|c|}
\hline 20 & 40 \\
\hline 21 & 37,5 \\
\hline 22 & - \\
\hline 23 & - \\
\hline 24 & 37,5 \\
\hline 25 & 37,5 \\
\hline 26 & 35 \\
\hline 27 & 37,5 \\
\hline 28 & 32,5 \\
\hline 29 & 40 \\
\hline 30 & 40 \\
\hline $\mathrm{N}=30$ & C. $Y=1040$ \\
\hline
\end{tabular}

Descriptive statics score of Spoken English course

\begin{tabular}{|c|r|}
\hline N & \\
\hline Valid & 28 \\
Missing & 2 \\
Mean & \\
Median & 37.1429 \\
Mode & 37.5000 \\
Std.Deviation \\
Range \\
Minimum & 37.50 \\
\hline
\end{tabular}

From the data above, it can be seen that the total score from 30 respondents of students' speaking score is 1040 . by applying the SPSS program, it shows that the mean of students' speaking score is 37.14; the median is 37.50 ; the mode is 37.50 , and the range is 12.50 . The standard deviation of students' speaking score is 2.86 . It also shows that the minimum score of students' speaking ability is 27.50 while the maximum score of students' speaking ability is 40.00 . The distribution of students' speaking score can be seen below: 


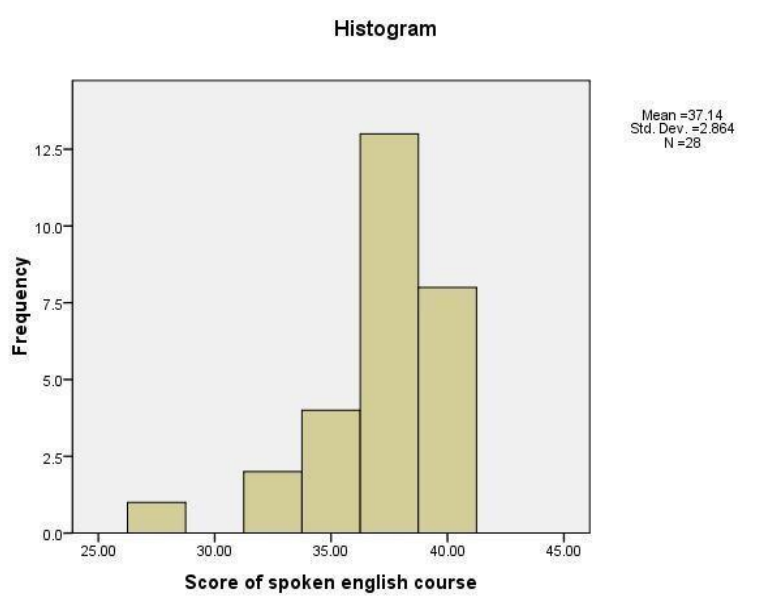

\section{D.The correlation between the students' motivation and their speaking ability}

The table below shows that the mean of score of spoken English course is 37.14 with the standard deviation 2.86 and the mean of students' motivation is 4.70 with the standard deviation 0.41 .

\begin{tabular}{|l|c|c|c|}
\hline & Mean & Std. Deviation & N \\
\hline $\begin{array}{l}\text { Score of Spoken } \\
\text { English course }\end{array}$ & 37.1429 & 2.86375 & 28 \\
\hline Motivation 1-30 & 4.7092 & 41114 & 29 \\
\hline
\end{tabular}

\begin{tabular}{|l|l|c|c|}
\hline \multicolumn{2}{|c|}{} & $\begin{array}{c}\text { Score of Spoken } \\
\text { English course }\end{array}$ & $\begin{array}{c}\text { Motivation } \\
1-30\end{array}$ \\
\hline $\begin{array}{l}\text { Score of } \\
\text { Spoken } \\
\text { English course }\end{array}$ & $\begin{array}{l}\text { Pearson } \\
\text { Correlation }\end{array}$ & 1 & 195 \\
\cline { 2 - 4 } & $\begin{array}{l}\text { Sig. (2- } \\
\text { tailed })\end{array}$ & & 321 \\
\cline { 2 - 4 } & $\mathrm{N}$ & 28 & 28 \\
\hline $\begin{array}{l}\text { Motivation 1- } \\
30\end{array}$ & $\begin{array}{l}\text { Pearson } \\
\text { Correlation }\end{array}$ & 195 & 1 \\
\cline { 2 - 4 } & $\begin{array}{l}\text { Sig. } \\
\text { tailed })\end{array}$ & 321 & \\
\cline { 2 - 4 } & $\mathrm{N}$ & 28 & 29 \\
\hline
\end{tabular}

From the calculation above, the researcher describes that $r$ coefficient (Pearson Correlation) is 0.195 and the sig. (2- tailed) is 0.32 .

\section{DISCUSSION}

At the previous chapter, the research question have been formulated: What is the level of students' motivation in Spoken English course at State Islamic University of Sunan Ampel Surabaya, what is the average of students' speaking score in Spoken English course at State Islamic University of Sunan Ampel Surabaya, how significant is the correlation between the students' motivation and their speaking ability at State Islamic University of Sunan Ampel Surabaya? Those are going to be discussed in this part based on the finding result. Based on the finding result above, the data is normally distributed and the research question has been verified through the SPSS program.

Considering the first research question, the result of the first question is students in Islamic University have a higher intrinsic motivation rather than extrinsic motivation. It means that the students who have intrinsic motivation will study hard and enjoy the teaching and learning process. Schunk (2012) says that "intrinsic motivation refers to motivation concerned in activities for its own sake". This caused of it has a good desire to do everything from inside themselves. Although the intrinsic of students' motivation of English Education Department in the $3^{\text {rd }}$ semester is higher than extrinsic, but the level is in medium level. It can be seen from the sum of extrinsic and intrinsic motivation (136.33 and 141.53).

Considering the second research question, the average of students' speaking score is 37.14. It can be seen from the data in the result section that the maximum score is 40.00 and most of the students got score 37.14-40.00. From there, we can conclude that the students have a high score in Spoken English course. When the students have a high score, it means that they are able to understanding and fluency in speaking English. As Brown (2004) says that students who are in Extensive level, they are able to extensive oral production includes speeches and oral presentation also storytelling.

The third research question investigated the significant correlation between the students' motivation and their speaking ability at State Islamic University of Sunan Ampel Surabaya.. unfortunately, the result is not appropriate in the previous study. If the result of some previous study has a correlation between motivation and speaking ability, but in this research is not. Tabrani (2003), the environment is everything which exists around us, which has correlation and gives influence to ourselves. For the correlation, it can be seen that the Pearson Correlation is 0.195 . Moreover, result included in the first category of interpretations which are $0.00-0.02$ that describes there is a very weak correlation between $X$ variable and $Y$ variable. It also can be seen from sig. (2-tailed) the result, it can be described that $0.32>0.05$. It means that there is no correlation between students' otivation and their speaking ability. 
[1] Bećirović, Senad. "The Relationship between Gender, Motivation, and Achievement in Learning English as a Foreign Language”. European Journal of Contemporary Education, 2017.

[2] Harmer, Jeremy. "The Practice of English Language Teaching". London:Longman, New Edition, 1991

[3] Istianti, Nerfi. The Correlation Between Students' Motivation in Learning Speaking and Their Speaking Ability. (A Thesis), 2013.

[4] McDonough,Joand Christopher Shaw."Materials and Method in ELT:A Teacher's Guide”. Cambridge:Blackwell Publisher.1993.

[5] Murcia,Cecle Marriane. "Teaching English as A Second Language". Boston Massachusetts: Heinle publishers. 1991.

[6] Rusyan, A Tabrani. "Pendekatan Dalam Proses Belajar Mengajar".Bandung: PT Remaja Rosydakarya. 2013.

[7] Santrock, W. John. "Educational Psychology". New York:McGraw- Hill,Second Edition.2004.

[8] Sari, Evi Ratna.“The Correlation Between Students' Motivation and Reading Comprehension of the Fourth Semester Students of The State Islamic University of Surakarta in the Academic Year of 2015/2016". Surakarta:Journal of IAIN Surakarta,2017.

[9] Schunk, Dale H. "Learning Theories an Educational Perspective".Boston: Pearson Education,Inc,Six Edition, 2012.

[10] Scrivener,Jim."Learning Teaching A Guide book for English Language Teachers. Oxford:Macmillan publisher, 2005.

[11] Marsh,Colin."Becoming A Teacher Knowledge, Skills and Issues". NewSouthWales: Pearson Australia,2010.

[12] Tarigan,Henry Guntur. "Berbicara:Sebagai Suatu Satuan Ketrampilan Berbahasa. Bandung:Angkasa, 1985.

As mentioned before in the previous chapter, motivation means the extent to which people make choices about the goals to pursue and the effort that people will commit to that pursuit. Dealing with the motivation, when the students have higher motivation, they will do anything to improve their performance in speaking English. Moreover, in this study, the researcher intends to prove the assumptions.

Baed on the description of data in the previous chapter, the motivation of the students is at the medium level. When it is compared between extrinsic and intrinsic motivation, the students have lower extrinsic motivation rather than intrinsic motivation. It can be seen from the result that the mean of extrinsic motivation is 4.54 while the intrinsic motivation is 4.88. In the other side, the score of students' speaking ability is high. It can be seen that from 30 respondents, most of them have spoekn English score between 37.14 until 40.00. The standard deviation of students speakig score is 2.86 . The data also shows that the minimum score of students' speaking ability is 27.50 while the maximum score of students' speaking ability is 40.00 .

Based on the calculation, it can be concluded that there is no correlation between the students' motivation and their speaking English ability. It can be seen that the Pearson Correlation is 0.195 . It is on the first category of interpretation which are 0.00-0.02. Moreover, the sig. (2taled) is 0.32 which is higher than 0.05 . So, in this research, there is no significant correlation between students' motivation and their speaking ability at the English Education Department students in $3^{\text {rd }}$ semester who have taken Spoken English Course in the $2^{\text {nd }}$ semester in 2018.
[13] Zolt'nDörnyei. "Motivation in second and foreign language learning". LanguageTeaching, 1998.

\section{REFERENCES}

